\title{
DEMOGRAPHIC CHANGES AND THEIR SPATIAL-SETTLEMENT CONSEQUENCES: LESSONS FROM EAST GERMANY AND HUNGARY
}

\author{
Tibor KOVÁCs ${ }^{\mathrm{a}}$ \\ ${ }^{a} \mathrm{PhD}$, habil., reader, geophilosopher; Eszterházy Károly University, 3300 Eger, Eszterházy tér 1., \\ Hungary; kovacs.tibor@uni-eszterhazy.hu
}

Cite this article: Kovács, T. (2016). Demographic Changes and Their Spatial-Settlement Consequences: Lessons from East Germany and Hungary. Deturope, 8, 3: 108-123

\begin{abstract}
Demographic shrinkage has created 'new' challenges in the spatial and urban development of the developed world and its semi periphery for nearly three and a half decades and it requires a different way of thinking and different solutions as well compared to previous development practices. Theoretical research and development activities in practice are further aggravated by the mono-minded mentality of society, economy and politics fallen a victim to charms of 'growth'; the slow recognition of the fact of spatial-urban shrinkage and the reluctance to deal with the problem (especially on the semi periphery). In this paper I would like to outline the settlement and spatial problems of demographic shrinkage and suggest certain theoretical solutions being aware of the fact that there is no universal solution for shrinkage; each and every settlement has to find and carry out their own solution - emphasising the mobilisation of the endogenous resources of the given region or settlement.
\end{abstract}

Keywords: demographic shrinkage; new philosophy of spatial and urban development; 'controlled reconstruction'; mobilization of endogenous resources; 'sailboat'-model

\section{INTRODUCTION}

\section{A new direction in urbanisation: shrinkage both in the west and east}

1984 is not only a symbol in world literature: that year was a turning point concerning the perception and assessment of changes in urban and spatial processes on Earth - by that time, besides the booming urban growth, characteristic of the developed world from the second half of the $20^{\text {th }}$ century, it was necessary for urban developer professionals in Rotterdam to record another, opposite urbanistic process. That was the demographic shrinkage (Schrumpfung) of some (big) cities in the centre regions (developed regions of Europe, certain urban regions of the USA), i.e. the reduction of population, including its complex social, economic, infrastructural, environmental and spatial consequences. 
Almost half a decade later, the regime changes in Eastern and Central Europe in 1989/1990 expanded this process further in space, i.e. a significant part of the European semi periphery ${ }^{1}$ also 'joined' the regions hit by the demographic shrinkage (Tab. 1), accumulating the transformation processes which had severe social-economic consequences themselves.

Table 1 Changes in the population (head) in certain Eastern-European countries since the regime change

\begin{tabular}{|l|c|c|c|c|c|c|}
\hline & $\mathbf{1 9 8 9 - 1 9 9 3}$ & $\mathbf{1 9 9 4 - 1 9 9 8}$ & $\mathbf{1 9 9 9 - 2 0 0 2}$ & $\mathbf{2 0 0 3 - 2 0 0 6}$ & $\mathbf{2 0 0 7 - 2 0 0 9}$ & $\mathbf{2 0 1 0 - 2 0 1 5}$ \\
\hline Bulgaria & 8669269 & 8384715 & 7928901 & 7718750 & 7606551 & 7202198 \\
\hline Estonia & 1567749 & 1425192 & 1366959 & 1351069 & 1363310 & 1313271 \\
\hline Latvia & 2667870 & 2501660 & 2364254 & 2319203 & 2270894 & 1986096 \\
\hline Lithuania & 3701968 & 3615212 & 3486998 & 3426678 & 3366357 & 2921262 \\
\hline Poland & 38183160 & 38609399 & 38242197 & 38173835 & 38135876 & 38005614 \\
\hline Hungary & 10373153 & 10321229 & 10198315 & 10097549 & 10045401 & 9849000 \\
\hline Romania & 23192274 & 22656145 & 22430457 & 21658528 & 21498616 & 21431298 \\
\hline
\end{tabular}

Source: own compilation based on EUROSTAT 2015

During peace time in the developed world neither theoretical researchers, nor regional and spatial developer professionals in practice met this phenomenon, let alone politicians. Yet from then on, they were forced to represent a significant change in their way of thinking: urbanisation and the development of the regions concerned (including towns as central places) should have been seen, planned and instructed according to a new paradigm. They were supposed to realise that instead of chasing 'controlled-led growth' they had better apply the process of 'controlled reconstruction', but actually it was/is very difficult even in the developed west, especially for the politicians believing solely in the fetish of 'growth' - the semi peripheral east showed a kind of fragmentation and lateness, as usual.

\section{Problems, characteristic features, reasons and consequences of urban and spatial shrinkage}

The process defined as a demographic crisis appeared in Europe as one of the basic problems of post-industry societies: it means the decline in childbearing, aging population, smaller

\footnotetext{
${ }^{1}$ In Southeast-Europe urbanisation also stopped in the early $90 \mathrm{~s}$, however was not the same de-urbanization process as in Western Europe, the driving forces were different. The Yugoslav wars also meant a breaking point for several towns (Hajdú - Rácz 2011, Rácz 2014).
} 
society, all in all we can record the new model of urban and spatial development, i.e. 'falling population - falling abilities'. In addition, certain regions and their towns - not exclusively, but partly as a consequence of deindustrialisation or de-economisation - possess weakening economic abilities, decreasing attractions and narrowing social-economic opportunities which (among others and including dangerous further effects) might lead to the comprehensive impairment of the local society, further increasing the regional, social-economic-cultural and environmental problems of the settlement, generating a downward spiral of urban-spatial regression.

Taking into account the above mentioned facts the reasons for shrinkage in detail are the following:

- structural weaknesses of the economy, lack of work and training places

- moving of young qualified workforce (long distance migration)

- moving of those with high(er) income (short distance migration/suburbanisation)

- permanent vacancy of flats, depreciation

- lack of rental incomes (flat owners)

- permanently low occupancy of infrastructural establishments (e.g. schools, nursery schools)

- increasing poverty

- aging population

- decreasing purchasing power (trade, enterprises)

- decreasing tax incomes

- increasing social expenditures (e.g. benefits)

- negative image

- low or missing willingness to invest in

- further increase of structural weaknesses of the economy (Hannemann 2003, based on Beer 2001).

\section{Reactions given to shrinkage in the centre and on the semi periphery}

It is a fact to welcome that focusing on the problem, within the centre regions (USA, Western Europe) there has been an increasing number of researchers and bibliography studying this issue (e. g. Bernt 2009; Bernt et al. 2012; Couchet al. 2012; Martinez-Fernandezet al. 2012; Neill - Schlappa 2016; Reckien - Martinez-Fernandez 2011, etc.), together with practical 
experiments over the past decades. However, it is still not paid appropriate scientific and pragmatic attention (nor its adequate way of handling it) to the topic of demographic shrinkage on the delayed semi periphery (e.g. in Hungary), although the problem of shrinkage can be felt by science (e. g. Gál et al. 2013; Turok- Mykhnenko 2007, etc.), politics, media and society increasingly.

It is a significant difference that the phenomenon has had a more extensive and thorough bibliography and experience concerning its pragmatic handling and realisation since the beginning of 2000 in the west (especially in Germany we are focusing on), whereas in Hungary there are only seeds of spatial-settlement analyses and pragmatic development activities carried out particularly from the point of viewof demographic shrinkage (e.g.Pirisi Máté 2014).

As we see it, to accept the problem after perceiving it and the difficulty of working out the different ways of handling it can be rooted in the following: for societies charmed solely by 'growth' it is very difficult at present to accept and handle this shrinkage mentally, they are not able to change their mentality, i.e. to go for 'planned redevelopment', a kind of 'regimented backdown' instead of chasing growth, as they can interpret these terms as loss and defeat.

In this paper I outline the settlement and spatial problem of demographic shrinkage drafted above and suggest some theoretical solutions being aware of the fact that there is no 'universal solution for shrinkage': each and every settlement has to find and realise it (studying the examples you can reach at several places, mostly in the west), acting as a kind of Baron Munchausen, pulling themselves out of the problems of spatial and settlement development caused by demographic shrinkage.

\section{OBJECTIVES AND METHODS}

\section{The aim of my research and its geographical dimensions}

Based on the problems outlined in the introduction my main aim is to draw attention to the demographic decline of certain rural regions (including their settlements), the root causes (which might be different in different regions, though there are general characteristic features as well) and the potential ways of solutions. All in all, this theoretical reasoning is to examine the main aspects of the problem of spatial-settlement population shrinkage and to show the potential development policy (spatial and settlement) reactions related to them. 
The theoretical research (the geographical target regions of which were the East German state of Saxony-Anhalt and the Hungarian Northern Great Plain) can be found on the borderline of social geography and spatial development. Regarding the approach and processing we can see traditional sociography and the tools used in modern spatial development.

\section{RESEARCH METHODOLOGY}

The methodology I used was rather complex - due to the complexity of the subject matter itself (in this summarising paper I mention mostly the secondary, theoretical ones):

- processing English, German and Hungarian literature

- analysing East German and Hungarian normative controls

- collecting, analysing and applying the related Hungarian and German central, regional and settlement statistical data

- interviews

- 'experienced geography'- 'being among people' (I took part in professional meetings, workshops, conferences on spatial development, urbanisation and rural/agricultural development, civilian meetings both in Hungary and Saxony-Anhalt).

Due to the above mentioned methods, besides applying the too 'antiseptic' mathematicalstatistical data, often distorting or covering geographical differences, I was able to gain a lot more differentiated and realistic picture with the help of these social geographical 'snapshots' during the theoretical study of shrinkage.

\section{Tasks related to settlement and spatial shrinkage}

Studying the shrinkage processes of rural regions and settlements it was shown by the East German and Hungarian research of the given problem that during the process of finding answers to the problems raised by negative demographic processes the following tasks arisein each type of the region:

- introduce the appearance of shrinkage at relevant regional levels

- denote reasons which might be different in different regions and

- outline potential steps/introduce steps taken, which must be different in different regions (e.g. in a big city compared to a rural region). 


\section{Shrinkage Everywhere - Differences in Regional-Settlement Levels; Reasons, Consequences, Tasks}

Accomplishing the above drafted tasks, based on the conclusions of my research I would like to highlight the differences between the given levels briefly, evaluating shrinkage processes:

- world-city, metropolis-region ('Gamma level cities' according to GaWC - Erdősi 2003) (e.g. Budapest, Berlin)

○ reasons: comprehensive, increasing social-economic changes: global, continental (and national) realignment of economy, production and services and international division of labour (global and continental transformation of centre-periphery relations); increasing competition in international markets; production plants leave cities; post- (de)industrialisation, de-economisation (i.e. the total economic decline of the region - Hannemann 2003) in developed (and moderately developed) regions are on the increase, breathlessness of growth (quantity), difficulties of development transfer (quality); new economy, offering new types of business sites; info technology on the increase, expansion of the virtual world, reduction of being forced to live on the same place, be fixed; over-crowdedness of the core of the city; suburbanisation; extreme individualisation among metropolitan population, change of consuming habits, undiscerning, very often superfluous and prestige consumption; change in female roles; pursuit of career and experience, extension of the time for having children, in addition to the decreased willingness, being single as being trendy

- consequences: transformation of city economy, devaluation and destruction of classical industrial zones (within cities, occupying a large area); partial depopulation of buildings, streets, districts; slums on the increase; impairment of real estates; inadequate number of good-quality, yet reasonably priced flats; degradation of man-made environment; the more and more expensive sustainability of the infrastructure; migration of highly-qualified, young(er) population into more developed countries; increasing social inequalities, total marginalisation of certain social layers, social decline, segregation, threat of emerging ghettos 
- action to be taken/steps already taken: creating a new way of mentality and town planning; defining the town as a national or continental pole to be developed; strengthening tertiary and quaternary sectors $(\mathrm{R}+\mathrm{D}+\mathrm{I})$; enhancing the role of knowledge centres; attracting services providing high added value; partial or total demolition of buildings; promoting rehabilitation functions of buildings (e.g. forming a new conference centre from an old industrial hall), creating new social places; increasing green areas of the region, ecological corridors in cities, green lungs, establishing a higher-level habitat; social appraisement of the region; together with the revitalisation of the physical environment; aimed social marketing

- large city region (with population more than 100 thousand peoplee.g. Magdeburg (earlier), Miskolc, Pécs)

- reasons: crisis and collapse of traditional (large-scale)industry; relocation of certain firms to the countryside from towns; partial or total closure of production or processing sites in towns; increasing unemployment; extracting effect of other cities (capitals) on mobile workforce; suburbanisation; sudden political change after the change of the regime (relative unpreparedness for operating local governments), occasionally ill-thought decisions on spatial arrangement (e.g. residential or industry-region allotments for suburban or extra-urban places for building flatsor for greenfield investments, which have become partly crisis areas today)

- consequences: partial depopulation of city centres, city expansion, riving of the city fabric; threat of creating fragmented city structure; increasing number of commuters, degradation of man-made and natural environment in cities; deterioration of the quality in infrastructure, increase of the costs to sustain it; decreasing rate of active people compared to the growth of those being nonactive; social imbalances; migration of the young towards the more developed regions or countries; aging population of cities; segregation; BUT! less dense city population can open new, free horizons for changing lifestyles, there might be fewer social conflicts, less waste of resources, there can be a decreasing tendency in nature utilisation

- actions to be taken/steps already taken: creating a new way of thinking and town planning; defining the town as a regional pole to be developed, its 
complex development in this direction; quality development of trainings and (higher) education (strengthening lifelong and lifewide learning); promoting transformation in economic structures; enhancing $\mathrm{R}+\mathrm{D}+\mathrm{I}$; revitalisation of the city centre, its renewal in extending functions, protection of historic buildings, revival of the city; appreciation of buildings by wrecking and clearing; forming family-friendly city centres; social town development; accessibility, modernisation of social transport

- small town region (with population of about 10-25 thousand people, e.g. Kisújszállás and its surroundings; Salzwedel and surroundings)

- reasons: decline of agriculture, ceasing of farmers' cooperatives, closures of industrial plants (e.g. light industry, food industry), re-organisation of the remaining plants, employing far less labour force, lack of adaptability to new circumstances among the major part of population; inadequate individual and community responses to new challenges (lack of social motivation: 'reducing population - reducing abilities')

- consequences: increasing unemployment; increasing number of abandoned, unmarketable real estates, their destruction; degradation of townscape, deterioration of the quality of physical environment in towns; threat of fragmented town structure; social instability; disruption of town society, crack and disappearance of the 'middle class', backsliding of the majority of lower layers, those whose existence becomes totally impossible are forced to move to the country

- action to be taken/steps already taken: strengthening activities of agriculture and forestry based on local capacities (focusing mainly on organic farming, producing biomass), creating processing industry based on them; changing consumer culture ('Buy local food from local producers - it is more environment-friendly and creates local workplaces'), development of accessibility of (micro)regions; intensive formation of social consciousness, enhancing of community cohesion

- peripheral rural region (certain parts of Nagykunság [Great Cumania]; Altmark those regions beyond the strictly statistical data of $120 \mathrm{head} / \mathrm{km}^{2}$ : peripheral state, undereducated human resources, incomplete, structurally retarded supply of 
workplaces, unfavourable employment conditions, the dominancy of agricultural structures, less advanced infrastructure, weak economic potential, migration, etc.)

- reasons: social-economic (semi) peripheral state; general crisis of the agriculture; migration of young, educated age group to (large) towns; exclusion of the poorest layers from the town, their moving to the countryside, social degradation, pauperisation, exporting deviance to the countryside

○ consequences: spaces becoming empty, more and more expensive infrastructure and services, (their ceasing because of insolvency), more and more difficult conditions of everyday existence; aging, impoverishment, degradation and pollution of man-made, natural and spiritual environment

- action to be taken/steps already taken: utilisation of abilities and capacities specific to the region, focusing on specialisation; development of education and trainings (restoration of the respect of manual jobs); 'rediscovering the country', restoring the traditional multifunctionality of work-living-free time; generating and using renewable energies; eco and organic farming, labour intensive production and employment; improvement of accessibility of regional centres, access to services; providing commuting and utilising modern information and communication technologies; development of rural tourism in a complex way; extending cultural supply; providing the possibility of taking part in local public life (make people feel they are able to form their lives); addressing and settling the young, inspiring them to have children.

\section{RESULTS}

As a summary of the above mentioned, a 'model of shrinkage' can be formed for all town categories and rural regions concerned - i.e. the social-economic degradation spiral threatening the shrinking towns (and as a result, the rural regions providing homes for them, too) usually is like the following (Fig. 1). 
Figure 1 Cumulative causal chain of regression in towns and regions

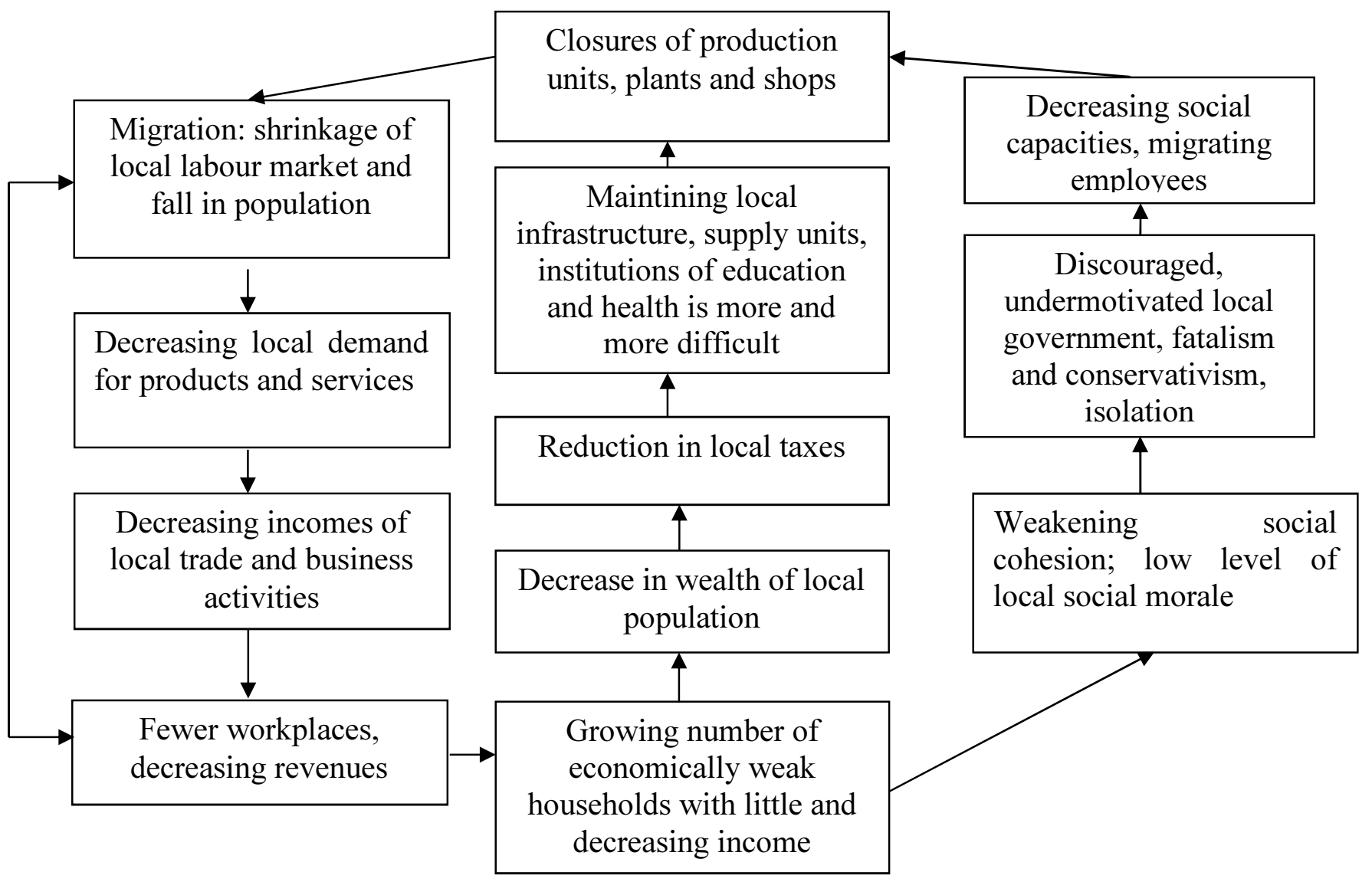

Source: Mayer - Knox 2009, 209

According to the above statements, experiments for solving the problem may be very complex, thus one comprehensive and beneficial development scheme or model for everyone and everywhere cannot be formed. However, towns facing the problem of shrinkage might consider the following points in their development (and in time relating the direct region as well), starting from the actual steps to the general strategic tasks (knowing and accepting the fact that shrinkage can mean the new way of the urban and regional development):

Concerning empty buildings the following transformation strategies can be applied in towns:

- planned demolition of buildings

- creating inner city green areas, green corridors, green lungs

- 'naturalisation', 'resuscitation' of nature in towns

- further utilisation of the remaining old buildings and the new spaces being formed due to demolition by a functional change, appropriate conversion for new target groups, e.g. 
- creating newly-built inner town buildings for new target groups (e.g. for young families)

- rehabilitation by functional change (e.g. converting old industrial areas/buildings into flats, art studios etc.)

Besides the actual physical intervention it is essential to 'rethink towns' (as they are not only enlarged sets of buildings but do have souls), i.e. the challenges of town development and town planning require a different approach, according to the following:

- it is necessary to reinterpret the term of urban space (both in philosophical and physical sense)

- it is urgent to rethink the term of the town in cultural, social and economic sense and also concerning space and utilisation, i.e. the paradigm shift of town development/planning is inevitable (from 'controlled growth' towards 'regimented back-down')

- strengthening and stimulating urban creativity is a must (rethinking, giving up routine activities, cooperation, communication)

- determination and courage are needed to define the differences between towns, to find, conceive, communicate and sell the unique features and specialities of settlements

- shrinkage has to be interpreted and applied as free physical and mental space

- once rethinking local society and culture, shrinking settlements have to be defined asspecial and peculiar laboratories of future economic development (www.ibastadtumbau.de; www.leipzigeragenda21.de).

As I see it, the above mentioned facts are essential and important conditions of handling the problem of shrinking towns and their regions, where special attention must be paid to the endogenous resources, the inner development potentials inherent (or absent) in local societies. This can be seen clearly in the case of Hungary, where huge amounts of EU aids have been streaming into since 2004, but especially since 2007, for different regional and settlement development projects (Hungary's net position in absolute value will be about 25 billion euros during 2014-2020, being the third in the ranking of member states, after Romania and Poland. The net position per head is improving from 2333 euros/head to 2513 euros/head, compared to the period of 2007-2013, Hungary being the second after Lithuania. In the ratio of GNI it means a $+3,6 \%$ net position, being also the second in the ranking, following Bulgaria Hetényi 2013), yet despite these figures a real breakthrough can be recorded neither socially 
nor economically (let alone sustainability or environment protection). What is the reason for my being so sceptical? Having theoretical and pragmatic experience of many years in the field of spatial and settlement development I dare to state that the very essential development base, starting point, i.e. developing the above emphasised human resources is still considered as secondary in Hungary. There are certain initiations and projects for the development and research of human resources: a recent example of it is the Research Group for the Development of Regional Economy, operating at Eszterházy Károly University. The group realising the problem and its significance - launched a research project in 2016 entitled 'Local capital, local knowledge, local employment in Heves county'. (The main aim of the project is to reveal how successful it was to enlarge the number of workplaces in different settlements of the region, using local sources, and to introduce those efficient methods which resulted in significant enlargement in employment. These initiations are far behind the required level, although their importance does not need any special explanation. As I see it, the inner, localregional resources should be mobilised in the field of spatial and settlement development knowing the fact that the generous donations of the EU will be likely to change (decrease) significantly since 2021, thus from then on the developments based on endogenous resources have to be in the forefront. The question is whether Hungary will be able to do that.

These questions raise the demand (or the lack of it) for social innovations of different regions and their settlements and the abilities to realise them. Social innovations typical of the rural regions (the ones I examined in East Germany and in Hungary) can be deduced from the following characteristics of the countryside (G. Fekete, 2014):

- low concentration (of population, enterprises, buildings): low concentration led to inadequate extension of services when applying principles of economies of scale too strictly

- being close to nature, which can be used as a resource and it requires taking responsibility as well

- distance from the centres, meaning a digital, informational separation, helplessness, inadequate accessibility of higher-level services

- slower cultural changes, which can be favourable for the preservation of cultural values, yet slow down the spread of innovations, too (G. Fekete 2011, 77).

Based on the above mentioned, we can compose the characteristic features of the rural regions, the aims to be achieved at the given places and their settlements, in addition, special tasks to be performed as follows (Tab. 2): 
Table 2 Potential fields of social innovation in rural regions

\begin{tabular}{|c|c|c|}
\hline Rural specification & Social aim & Special tasks \\
\hline \multirow[t]{2}{*}{ low concentration } & $\begin{array}{l}\text { reducing deprivation / } \\
\text { promoting catching } \\
\text { upby projects of } \\
\text { developing human } \\
\text { resources }\end{array}$ & $\begin{array}{l}\text { introduction of alternative (small-scale) ways of } \\
\text { services: education, culture, health, social care, } \\
\text { public utilities }\end{array}$ \\
\hline & $\begin{array}{l}\text { regional and social } \\
\text { integration }\end{array}$ & $\begin{array}{l}\text { arranging co-operations and integrations, creating } \\
\text { inner networks, improving horizontal transport }\end{array}$ \\
\hline \multirow[t]{2}{*}{$\begin{array}{ll}\text { being } & \text { close to } \\
\text { nature } & \end{array}$} & $\begin{array}{l}\text { providing healthy living } \\
\text { environment for future } \\
\text { generations }\end{array}$ & $\begin{array}{l}\text { strengthening environmental sustainability: nature } \\
\text { protection, land management, forestation, use of } \\
\text { alternative energy sources, waste disposal, } \\
\text { modernisation of flats, settlement-maintenance }\end{array}$ \\
\hline & $\begin{array}{l}\text { providing living, } \\
\text { inspiring autonomy, } \\
\text { settling the young }\end{array}$ & $\begin{array}{l}\text { utilisation of local (natural and cultural) resources: } \\
\text { production of region-specific food, extending } \\
\text { recreational opportunities, offering real estates }\end{array}$ \\
\hline \multirow[t]{3}{*}{$\begin{array}{l}\text { slower cultural } \\
\text { changes }\end{array}$} & $\begin{array}{ll}\text { promoting the } \\
\text { connection to the } \\
\text { knowledge society }\end{array}$ & $\begin{array}{l}\text { enlargement of knowledge supply: development of } \\
\text { local and professional knowledge, computer-literacy } \\
\text { (trainings) }\end{array}$ \\
\hline & $\begin{array}{l}\text { preserving identity, } \\
\text { enlarging resources }\end{array}$ & $\begin{array}{l}\text { preservation of cultural heritage, cultivating } \\
\text { traditions: collecting, introduction of exhibits, a } \\
\text { 'fair' marketization of this heritage }\end{array}$ \\
\hline & $\begin{array}{l}\text { reaching } r \text { direct } \\
\text { participation, extending } \\
\text { capacities }\end{array}$ & adequate governing: strengthening communities \\
\hline $\begin{array}{l}\text { physical and mental } \\
\text { distance from the } \\
\text { centres }\end{array}$ & $\begin{array}{l}\text { moderation of regional } \\
\text { drawbacks }\end{array}$ & $\begin{array}{l}\text { strengthening urban-rural relations: promoting } \\
\text { commuting, arranging markets and providing access } \\
\text { to them, } \\
\text { creating (physical, informational, social) networks, } \\
\text { being present and representative in opinion-forming } \\
\text { and decision-making process of the town and the } \\
\text { region }\end{array}$ \\
\hline
\end{tabular}

Source: G. Fekete 2014, 77

\section{DISCUSSION}

Demographic shrinkage together with its complex spatial-settlement impact system and consequences is inevitable (at least in the case of my theoretical research in the state of Saxony-Anhalt and Northern Great Plain in Hungary). However, it is still problematic to perceive, interpret and analyse the whole issue and work out potential solutions, let alone their realisation. In addition, concerning these facts - besides significant differences - west and east show certain similarities as well, since the differences in the mentality of politics, science and those of practical developers can be recorded there and here, too, certainly, taking into account the differences in specifications according to countries and places. 
The opposition can be seen well in the following: the task of science is to observe and demonstrate facts; it has changed (urban) life over the past centuries based on empiricism. Without science it is impossible to maintain either present living conditions, or providing them in the future (very often it seems it is not possible even with it, or because of it, yet it can be the subject of another article). That is the reason why politics - at least in theory - is dependent on scientists' suggestions. However, it is rather thought-provoking that once the commitments of scientists are proclaimed, they are questioned by many from the realm of politics: saying, they are not realistic, would cost too much, not feasible, not compatible with other issues, all in all, due to current circumstances impossible to realise. Politicians or representatives being concerned in the procedure and those supporting them in different parties and economic hinterland - very often do not pay attention even to obvious facts. Their attention is seized by other 'facts', tending to people's short-term general feeling and finding the possibilities of obtaining political power and their personal positions (incomes), instead of the issues in the middle and the long run, which would require complex and difficult solutions and go well beyond the period of elections.

Knowledge sets of sciences and politicians are obviously different. What scientists consider a 'fact' to be justified, politicians refer to as simply opinions of those politically incompetent, while they consider the things explained to the voters as 'political (and therefore real)' facts. Because of these I find it very difficult to channel such a phenomenon like socialeconomic and spatial-settlement shrinkage and its consequences into the public: researchers have to study, argue, consult, convince politicians and their voters - yet they should be communicative, be able to handle the media: it is a difficult, complex and dicey challenge; perhaps not totally hopeless.

We are convinced, however, that despite the difficulties, this issue, i.e. the challenges of development policy forced by demography will be more and more in the forefront of the Eastern European, including the Hungarian professional, scientific and everyday scope of interest in the following years, as our everyday life and its quality, our social-economic, political and environmental relations will be influenced by them - whether politics and society like it or not. 


\section{CONCLUSION}

Taking into account the differences, we can state generally that solutions have to be unique, specific to the given regions or towns, but basically the following should be taken into consideration when analysing and developing:

- challenges happening due to demographic changes must be taken into account

- the issue of the system of central places has to be dealt with thoroughly

- together with shaping of technical infrastructure and also

- the issues of a complex and sustainable development of society, economy and environment.

In my present article I have demonstrated (and hopefully have proved as well) that in some countries, regions and settlements of Europe (especially in East Germany and in Hungary) spatial and settlement development processes will be defined by demographic shrinkage, which will be felt actually in every field of life. Handling the problems will be inevitable, at local, regional and the topmost levels, as the government should have an important function in consolidating the shrinking regions, it might moderate or partly balance the emerging and ever increasing drawbacks of certain shrinking regions when allocating the decreasing, yet still available sources.

As a conclusion of the analysis of the East German and Hungarian situations, the importance of the tight, continuous and sustainable partnership must be pointed out, which besides the decreasing material opportunities could show a new, strengthening and increasing direction of population participation for development policy, as future developments can be the results of only an efficient, effective local and regional partnership, maintained in the long run.

\section{REFERENCES}

Bernt, M. (2009). Partnerships for Demolition: The Governance of Urban Renewal in East Germany's Shrinking Cities. International Journal of Urban and Regional Research 3. pp. 754-769.

Bernt, M., Cocks, M., Couch, C., Grossmann, K., Haase, A., \& Rink, D. (2012). Shrink Smart. Policy Response, Governance and Future Directions, Research Brief No. 2, Helmholtz Centre for Environmental Research - UFZ, Leipzig.

Couch, C., Cocks, M., Bernt, M., Grossmann, K., Haase, A., \& Rink, D. (2012). Shrinking cities in Europe. Town\& Country Planning, pp. 264-270.

Erdősi F. (2003). Globalizáció és a világvárosok által uralt tér II. Tér és Társadalom, XVII. évf. 4. sz., pp. 1-16.

Gál, Z., Lux, G., \& Illés, I. (eds.) (2013). Danube Region: Analysis and Long-Term Development Trends of the Macro-Region. Institute of Regional Studies, Centre for 
Economic and Regional Studies, Hungarian Academy of Sciences, Pécs (ESPON ET 2050 project).

G. Fekete, É. (2011). Elements of Social and Solidarity Economy (SSE) in the Hungarian Local Development. 'Club of Economics in Miskolc' TMP, 7, 1, pp. 17-27.

G. Fekete, É. (2014). A szociális és szolidáris gazdaság csírái a magyarországi vidéki térségekben. Deturope - The Central European Journal of Regional Development and Tourism, Vol. 6, Issue 3, ISSN 1821-2506, pp. 69-84.

Hajdú, Z., , \& Rácz, Sz. (2011). Urbanisation, state formation processes and new capital cities in the Western Balkans. AUPO Geographica. 2. pp. 63-77.

Hannemann, C. (2003). Schrumpfende Städte in Ostdeutschland - Ursachen und Folgen einer Stadtentwicklung ohne Wirtschaftswachstum. In: Berwe, K. (Ed.): Politik und Zeitgeschichte, B28, pp. 16-23.

Hetényi, G. (2013). A többéves pénzügyi keretről szóló tárgyalások eredményei magyar szempontból. Európai Tükör, XVIII. évf. 1. szám, 2013. tavasz; ISSN 1416-6151, pp. 46-55. http://eu.kormany.hu/download/9/6d/60000/EU\%20Tukor\%2013-01.pdf (letöltve: 2016. március 26.)

Martinez-Fernandez, C., Kubo, N., Noya, A., \& Weyman, T. (eds.) (2012): Demographic Change and Local Development: Shrinkage, Regeneration and Social Dynamics. OECD Working Papers, Paris, OECD/LEED.

Mayer, H., \& Knox, P. L. (2009). Cittaslow: Ein Programm für Nachhaltige Stadtentwicklung. In: Popp, H. - Obermaier, G. (Hrsg.): Raumstrukturen und aktuelle Entwicklungsprozesse in Deutschland. Bayreuther Kontaktstudium Geographie, Band 5, pp. 207-221.

Neill, WJV., \& Schlappa, H. (eds.) (2016). Future Directions for the European Shrinking City. RTPI Library Series, Routledge Taylor \& Francis Group, London.

Pirisi G., \& Máté É. (2014). Zsugorodó kisvárosok - kincstári optimizmus. In: László M. (föszerk.): Területfejlesztés és Innováció, 8. évf. 2. szám, Pécs, ISSN 1789 - 0578, pp. 28-39. http://www.terinno.hu/szamok/teruletfejlesztes_es_innovacio_2014_2.pdf

Rácz, Sz. (2014). New Integration Period? Changing Tendencies of the Urban Network in South East Europe. Deturope 6, 2, pp. 46-63.

Reckien, D., \& Martinez-Fernandez, C. (2011). Why do cities shrink? European Planning Studies 8., pp. 1375-1397.

Turok, I., \& Mykhnenko, V. (2007). The trajectories of European cities, 1960-2005. Cities 3., pp. 165-182.

http://www.iba-stadtumbau.de/index.php?principles (letöltve: 2016. március 26.)

http://www.leipzigeragenda21.de/de/gute_geschaefte.asp?mm=8 (letöltve: 2016. március 26.) 